through a pressure which the earth's crust is not rigid enough to resist, and that so long as this pressure is sustair.ed they must remain at least stationary. There is no proof anywhere that the pressure that caused the elevation is now removed, but there are frequently indications, such as earthquakes and landslips in mountain chains, that it exists and is even on the increase. On the other hand, there is no evidence of any kind to show that some, especially of the older mountain chains, are not sinking, though subsidence in such cases would be very difficult to detect. Besides this it is conceivable that when the force which has squeezed the crust into folds has ceased to be exerted it is not flexible enough to regain its original horizontal position, but will remain in folds, and as there is no increased thickness, and consequently no addition of weight, but on the contrary a continual loss from denudation, there is no reason why they should not retain their fosition upon the hypothesis of a continuous molten layer subjected to greatest pressure at its lowest levels. Dr. Fisher even assumes that the mere removal of weight from them by denudation, and its accumulation on their flanks, would suffice to cause a continuous upheaval. The deflection of the plumbline has shown that the density of the crust beneath mountains must be less than that below the plains, and the relatively slow rate at which heat increases in boring through them show's also that the pressure there cannot be so great. Though strata are compressed into a smaller area through the folding, it is doubtful whether the aggregrate pressure on the liquid layer in such regions is at all increased, while in elevated plains it obviously cannot be so, as there is in that case no direct increase of weight. It thus seems as if it were as necessary that the crust of the earth should yield to increasing pressure as that the sea should roughen under the wind, and the apparently arbitrary upheavals ard depressions are brought under a definite law. The greatest depths of the ocean would ever deepen and its superficial area tend to diminish, while that of the dry land would increase, and its mountain chains reach higher elevations. The theory appears in harmony with the truths of geology and of astronomy, for the records of Palæozoic times show neither evidence of great depth of sea nor mountainous elevation on land, the organic remains pointing to a little varied surface. The bighest mountains are geologically the most recent, and evidence of deep seas increase towards the Cretaceous period while our satellite, whose evolution may bave progressed more quickly than ours, has relatively far greater, more numerous, and more abrupt elevations than the earth.

Somewhat similar conclusions to these have been arrived at in the "Physics of the Earth's Crust," by Dr. Fisher. Without presuming to compare the present superficial treatment of the subject with that great and philosophical work, some important differences will be observed between the views there expressed and these, as well as some entirely new observations and extensions of the theory. The views advocated are still so far from being generally accepted by geologists that their publication in NATURE will doubtless put many in possession of facts and inferences which are in a general way only accessible to those who have leisure to gather them from less popular publications.

J. STARKIE GARDNER

\section{THE ISCHIA EARTHQUAKE}

$\mathrm{O}^{\mathrm{N}}$ $\mathrm{NE}$ of the most disastrous earthquakes on record occurred in the little Island of Ischia, in the Bay of Naples, on the evening of July 28 . It was only in March 1881 that a similar catastrophe occurred at the same place. The island is a favourite summer resort of Romans and Neapolitans, and Casamicciola, where the destruction was greatest, was crowded with strangers. The full extent of the loss of life has not yet been ascertained; but up to the present it is estimated that at least 4000 have been killed, and very large numbers wounded. The earthquake occurred at half-past nine, when strangers and natives were enjoying themselves in various ways under a cloudless sky with not a breath of air stirring. Not the slightest warning seems to have preceded what occurred; in the space of fifteen seconds Casamicciola was a heap of ruins, while a similar fate overtook the smaller towns of Forio, Laco Armino, and Fontana Serrata. At present we can only record the facts of the case; when further details are to hand it may be possible to throw some light on the real cause of the catastrophe. Besides the first shock, which lasted fifteen seconds, other two were noticed immediately after. Prof. Palmieri is stated to have expressed the opinion that the catastrophe was caused by a sinking in of the level, and not by an earthquake. On the 3 Ist there was another slight shock; while Vesuvius is in a state of active eruption. A Rhenish journal states that on Saturday night, about the time when the Ischia earthquake occurred, a tremendous motion of the earth was distinctly felt at Wiesbaden. On the morning of the $3 i s i$ also, it may be noted here, a shock of earthquake was felt in Oporto, lasting two seconds, with direction east and west; it naturally caused great consternation. Two shocks are reported to have occurred on the same day at Gilroy, California. With regard to the volcanic Monte Epomeo in the Island of Ischia, we may say that its last recorded eruption took place in 1302 .

We are glad to learn that Dr. Dohrn, director of the Naples Zoological Station, who was in Ischia at the time, escaped unhurt.

\section{THE AGRAM EARTHQUAKE ${ }^{1}$}

$\mathrm{I}$ connection with the Ischia Eartbquake, the official report of the Agram Earthquake of three years ago may not be without interest. The detailed report by Herr Hantken von Prudnik contains all the information which be had been able to collect regarding the severe earthquake with which the district surrounding the town of Agram in Croatia was visited on November 9, 1880. Herr von Prudnik gives not only an exhaustive narrative of his own observations of the effects of the earthquake, made a few days after its occurrence, but also some account of careful observations made by inhabitants of the district where the earthquake actually took place ; and his memoir is full of most interesting matter to seismologists. The district is situated in an area within which earthquakes are of very frequent occurrence, for Herr von Prudnik gives a long list with descriptive notes and dates, beginning with March 26, I 502, and coming down to Nov. 9, I880, but most of them within the present century, of earthquake-shocks, some of which seem to have been severe, which have been felt in the locality. A few selfregistering seismographs erected in suitable places in the district would yield, we think, much valuable information and would detect many of the smaller motions, partaking rather of the nature of tremors, which are no doubt frequent, but which, although of great seismological importance, remain unnoticed where such appliances are not in use.

With regard to the earthquake of November 9 itself, the shock seems to have been very severe, causing as it did, besides loss of life, a vast amount of damage to public and private buildings, especially churches. The details of the damage done, given by Herr von Prudnik, are very interesting, and illustrate very clearly the conclusions which have already been arrived at by seismologists as to the effects of the conformation of the ground in the neighbourhood of a building, and of the structure of the building itself, in diminishing or in aggravating the

I "Das Erdketen ron $\triangle$ gram in Jahre 1880 ." Bericht an das k. ung Ministerium für Ackerbau, Industrie, und Handel, eingereicht vcn Max Hantken von Prudnik, gewesenem Director der k. ung. geologischen Anstalt. (Lendon: Trübner and Co., 1882.) 
destructive action of an earthquake. For example, we find that in some cases well-built and substantial churches and houses suffered severely, while crazy erections, considered to be almost on the point of falling to pieces, received little or no disturbance. This apparent paradox is of course explained by the fact that the sudden backward and forward motions of the ground on which a building stands, although they may be, and in general are, of limited extent, bring very severe stresses to bear on high masses of masonry, which although it may be of the very best construction has little strength to resist the strains produced; while more loosely put together, and, in ordinary circumstances, insecure structures are capable of yielding to the necessary extent and escape unharmed. Again, when an earthquake consists of approximately periodic movements of the ground, buildings or parts of buildings, whose natural period of free oscillation coincides with, or is some multiple of the period of the disturbance, yielding to the repeated and conspiring impulses, oscillate with increasing range, until return to the equilibrium position is no longer possible and they collapse in ruins.

A phenomenon observed in connection with many other earthquakes, the rotation of upright pillars such as gravestones and monuments, on their bases, was very remarkable in this. Herr von Prudnik does not accept the explanation which has been offered by Mallet and others that the rotation is due to vorticose movements of the earth's surface; and he offers an explanation which, though not quite clearly put dynamically, seems to point to the true theory. The cause of the phenomenon no doubt is that the first sufficiently severe shock causes the body to tilt over in the direction from which the shock proceeded, and immediately after, the shock, although rectilinear in direction, makes the body turn round on the corner or portion of an edge on which it for the moment rests. This explanation has been tested with model gravestones and obelisks placed on a table, which could be shaken so as to imitate the motions of the ground during an earthquake, and found to answer perfectly. ${ }^{1}$ The circumstance that in the earthquake at Agram, as elsewhere, the gravestones at one particular place were for the most part rotated in one direction accords well with this explanation, as no doubt the gravestones there were all set so as to face in one direction.

Herr von Prudnik is not of opinion that the earthquake was due to volcanic agency, but thinks that it was produced by the yielding to mutual stresses of the materials underlying the Slamen mountain, which lies along the middle of the area in which the destructive effects were most marked. This mountain occupies an area roughly elliptical in shape, about 4.5 kilometres (6 Meilen) long by 3 kilometres broad, and is composed for the most part of slate, limestone, and dolomite surrounded with strata consisting mainly of marl. To this mountain all the effects point as the locality in which the earthquake originated; but here again we think the use of selfregistering seismographs would be of great service in giving definite information. This would also give most valuable information as to the velocities of propagation of earthquake motions in strata of different materials. In the present case the disturbance travelled from Agram to Vienna in twelve seconds, which gives a velocity of propagation of $2 \cdot 2$ kilometres per second. It is not stated, however, how the exact times were observed.

Among the details of the many interesting phenomena, we find a very careful account of an outbreak of "mud volcanoes" at Reznik, a place about 8 kilometres westsouth-west of Agram ; but for details as to this and many other important points, we can only refer our readers who are interested in seismology to the memoir, which will well repay perusal.

IVide Milne and Gray on "Earthquake Observations and Experiments," Phil. Mag., November r 88 r.

\section{NOTES}

WE are enabled to give the text of the telegram received in Stockholm this week from the Swedish circumpolar observation party, which has wintered at Spitzbergen. The news is the first received from the expedition since October last:- "Cape Thordsen, July 4 th, I 883 . This message will be forwarded tomorrow to Capt. Startschin with the boat fetching our first mail this year. The wintering of the expedition has in every respect been attended with success, particularly as the scientific researches have throughout been carried on exactly in accordance with the regulations formulated by the International Polar Commission. Hydrographical and magnetic studies have also been pursued on the ice in the Ice Fjord, as well as parallax measurements of clouds, and observations as to the temperature of the air, the snow, and the earth. The winter has on the whole been mild ; the greatest cold occurring on January 2, when the ther. mometer registered $35^{\circ} 5^{\circ} \mathrm{C}$. below freezing point. Storms have been few. Since September last the following buildings have been erected:-A hut on a mountain at an elevation of 2 \%o metres, containing the anemometer and the wind-fan, which were read by a self-registering electrical apparatus; two astronomical observatories; another magnetic hut; a bath-house, a forge, and a wood storehouse. The dwelling house and working room have also been enlarged. The following game was shot during the winter : $6 \mathrm{I}$ ptarmigans, 9 reindeer, 18 wild geese, 20 foxes, and some wild fowl. With continuous labour, plenty of food and drink, and frequent baths, the members of the expedition have throughout enjoyed excellent health. Descriptions of the nature, our labour and life here during the wintering will follow."

Ar the meeting of the Scottish Meteorological Society held on Thursday last week it was announced that upwards of 4500 . had been already subscribed to establish the Meteorological $\mathrm{Ob}$,ervatory on the top of Ben Nevis. The subscriptions vary in amount from $200 l$. to one penny, and the subscribers include Her Majesty the Queen and all classes of her subjects, and town councils and other corporate bodies in all parts of the United Kingdom. The road to the top of Ben Nevis is nearly halt finished. The building will be commenced early this month, and it is contemplated that the portion to be completed this season will be ready at the end of October for the three observers, who will begin their regular observations on November $\mathbf{I}$.

MR. MUNDella in presenting his educational budget the other night had nothing but essential progress to report. The cry of overworking the ohildren was introduced by some of the speakers, but Sir John Lubbock pointed out that monotony and not overwork was the real weakness of the present system, and that the tendency was to cultivate the memory at the expense of the observing faculty. The real remedy, as he pointed out, is to introduce greater variety into the elementary course, and above all to make practical science teaching an essential part of the curriculum.

From a statement issued with reference to the Rolleston Memorial we learn that the total sum subscribed is $1183 l .5 s .0 d$., to which is added $59 l .7 s .5 d$, dividends paid on sums invested from time to time in Consols before the list was closed. From this total have been deducted secretaries' expenses, charges for printing, advertising, \&c., 36l. 16s. 9d., leaving a capital sum of 1205l. I 5s. $8 d$. invested in $1200 l$. Three per Cent. Consols. This sum has now been transferred to the chancellor, masters, and scholars of the University of Oxford, and accepted by them as the Rolleston Memorial Fund. The fund, it has been decided, will be expended in the institution of a prize to be awarded every two years for original research in any subject comprised under the following heads :-Animal and Vegetable Morphology, Physiology and Pathology, and Anthropology, to be selected by 